\title{
EFFECTS OF NICKEL AND NITROGEN SOIL FERTILIZATION ON LETTUCE GROWTH AND UREASE ACTIVITY ${ }^{(1)}$
}

\author{
Thomas Carlos Oliveira ${ }^{(2)}$, Renildes Lúcio Ferreira Fontes ${ }^{(3)}$, Sebastião Tavares de \\ Rezende $^{(4)}$ \& Víctor Hugo Alvarez V. ${ }^{(3)}$
}

\begin{abstract}
SUMMARY
Nickel is a micronutrient involved in nitrogen metabolism and a constituent of the urease molecule. Plant growth and urease activity were evaluated in lettuce (Lactuca sativa $\mathrm{L}_{\text {.) }}$ grown in soil-filled pots in a $2 \times 8$ factorial design with two nitrogen $(\mathrm{N})$ sources and eight $\mathrm{Ni}$ rates, with five replications. Nitrogen was applied at $200 \mathrm{mg} \mathrm{dm}^{-3}$ (half the dose incorporated into the soil at seedling transplanting and half top-dressed later) using the sources $\mathrm{NH}_{4} \mathrm{NO}_{3}(\mathrm{AN})$ and $\mathrm{CO}\left(\mathrm{NH}_{2}\right)_{2}(\mathrm{Ur})$. The Ni treatments $\left(0,2,4,8,12,16,24\right.$ and $\left.32 \mathrm{mg} \mathrm{dm}^{-3}\right)$ were applied as $\mathrm{NiCl}_{2}$. The shoot dry-matter yield, leaf urease activity, $\mathrm{Ni}$ levels in the lettuce leaves and Ni levels extracted from soil with Mehlich-3 (M-3) and DTPA were determined. In the plants supplied with AN, the shoot dry-matter yield was higher than in those supplied with Ur. There was no difference in shoot dry matter in response to soil-applied $\mathrm{Ni}$. The leaf urease activity increased with $\mathrm{Ni}$ application, regardless of the $\mathrm{N}$ source. The extractions with M-3 and DTPA were efficient to evaluate Ni availability for lettuce in the Red-Yellow Latosol.
\end{abstract}

Index terms: ammonium nitrate, urea, plant nutrition, Lactuca sativa $L$.

\section{RESUMO: EFEITOS DA ADUBAÇÃO COM NÍQUEL E NITROGÊNIO NO CRESCIMENTO E NA ATIVIDADE DA UREASE EM ALFACE}

Níquel é um micronutriente envolvido no metabolismo de nitrogênio e é componente da molécula da urease. Foram avaliados o crescimento de plantas e a atividade da urease em alface (Lactuca sativa L.) cultivada em solo em vasos, em experimento fatorial $2 x 8$, com duas fontes de nitrogênio $(N)$ e oito doses de $\mathrm{Ni}$, com cinco repetições. $\mathrm{O} N$ foi aplicado ao solo (200

\footnotetext{
(1) Part of Master degree dissertation of the first author submitted to the Universidade Federal de Viçosa - UFV. Received for publication in August 28, 2012 and approved in March 18, 2013.

(2) Agronomist, Master's degree in Soil and Plant Nutrition, Soil Departament, UFV. Av P. H. Rolfs, s/n. CEP 36570-000 Viçosa (MG), Brazil. E-mail: thomas.oliveira@ufv.br

(3) Professor of Soil Departament, UFV. E-mail: renildes@ufv.br; vhav@ufv.br

(4) Professor of Biochemistry and Molecular Biology, UFV. E-mail: sresende@ufv.br
} 


\begin{abstract}
$\left.m g \mathrm{dm}^{-3}\right)$, incorporando-se metade no transplantio das mudas e a outra metade, mais tarde, na superfície do solo, utilizando-se nitrato de amônio $\left(\mathrm{NH}_{4} \mathrm{NO}_{3}\right)$ e ureia $\left[\mathrm{CO}\left(\mathrm{NH}_{2}\right)_{2}\right]$. Os tratamentos com $\mathrm{Ni}\left(0,2,4,8,12,16,24 \mathrm{e} 32 \mathrm{mg} \mathrm{dm}^{-3}\right)$ foram aplicados, usando-se cloreto de níquel $\left(\mathrm{NiCl}_{2}\right)$. Produção de matéria seca, atividade da urease e do Ni nas folhas de alface e Ni no solo (Mehlich-3 e DTPA) foram determinados. A produção de matéria seca nas plantas supridas com $\mathrm{NH}_{4} \mathrm{NO}_{3}$ foi maior do que nas supridas com $\mathrm{CO}\left(\mathrm{NH}_{2}\right)_{2}$. Não houve diferença na produção de matéria seca das folhas em resposta à aplicação de Ni ao solo. A atividade da urease aumentou com o incremento das doses de Ni, mas não se alterou em razão da fonte de $N$ utilizada. As extrações com Mehlich-3 e DTPA foram eficientes para avaliar a disponibilidade de Ni para alface no Latossolo Vermelho-Amarelo.
\end{abstract}

Termos de indexação: nitrato de amônio, ureia, nutrição de plantas, Lactuca sativa $L$.

\section{INTRODUCTION}

Nearly seven decades ago, crop responses to the application of nickel (Ni) fertilizer in common bean (Phaseolus vulgaris L.), potato (Solanum tuberosum L.) and wheat (Triticum aestivum L.) were described by Roach \& Barclay (1946). In 1975, Dixon et al. (1975) found that $\mathrm{Ni}$ is a component of urease, a ubiquitous metalloenzyme present in plants, and later on, based on works by Eskew et al. $(1983,1984)$ and Brown et al. (1987), Ni was classified as a micronutrient (Salisbury \& Ross, 1992; Marschner, 2008). However, research with Ni has mainly addressed its toxic effects on plants and on how Ni-hyperaccumulator plants respond to high $\mathrm{Ni}$ concentrations. Apparently, $\mathrm{Ni}^{2+}$ reaches toxicity levels in the shoots first, but higher $\mathrm{Ni}^{2+}$ activities can also be toxic to the roots, decreasing growth and inhibiting lateral root formation (Kopittke et al., 2007). Although $\mathrm{Ni}$ is an important environmental contaminant, its action mechanism in plants is not yet clear (Sengar et al., 2008)

It is known that $\mathrm{Ni}$ is directly related to the nitrogen $(\mathrm{N})$ metabolism of plants because $\mathrm{Ni}$ deficiency impairs the urease activity, resulting in accumulation of urea in the plant. Further evidence of the $\mathrm{Ni}$ requirement for $\mathrm{N}$ metabolism comes from the observation that the accumulation of urea in $\mathrm{Ni}$ free urea-based media caused growth suppression and a deficiency of physiological N (Gerendás et al., 1998). The urea absorbed by a plant has to be broken down to $\mathrm{CO}_{2}$ and $\mathrm{NH}_{3}$ for $\mathrm{N}$ assimilation and to prevent urea accumulation in the plant (Marschner, 2008). The Ni-metalloenzyme urease catalyzes the initial step of the urea hydrolysis to $\mathrm{CO}_{2}$ and $\mathrm{NH}_{3}$ (Mulrooney \& Hausinger, 2003). Therefore, higher urease activity mediated by $\mathrm{Ni}$ (Eskew et al., 1984; Brown et al., 1987; Marschner, 2008) helps to prevent urea accumulation in the plant. Gerendás \& Sattelmacher $(1997 a, b)$ verified the need for Ni for urease activation, for plant growth on urea-based media and for recycling endogenous urea. In rice grown in nutrient solution, Gerendás et al. (1998) found that in plants supplied with urea and $\mathrm{Ni}$, the growth was impaired at the lower levels of $\mathrm{Ni}$, whereas in plants supplied with $\mathrm{NH}_{4} \mathrm{NO}_{3}$ and $\mathrm{Ni}$, growth was not affected by the micronutrient.
In nodules of $\mathrm{N}$-fixing plants, the hydrogenase catalysis of the reversible oxidation of molecular hydrogen increases in response to $\mathrm{Ni}$ (Klucas et al., 1983), suggesting that there is a role of $\mathrm{Ni}$ in the symbiotic fixation of N. Recently, Bai et al. (2006) reported that both $\mathrm{C}$ respiration and $\mathrm{N}$ metabolism are sensitive to Ni nutrition and that circumstantial evidence indicates the possibility of undiscovered roles of $\mathrm{Ni}$ in plant nutritional physiology. Malavolta et al. (2006) showed that high levels of $\mathrm{Ni}$ in citrus flowers increased the urease activity with production of $\mathrm{NH}_{3}$. $\mathrm{Ni}$ applied in the flowering stage would increase the flowering and the percentage of fruit set; hence, the foliar application of $\mathrm{Ni}$ associated to $\left(\mathrm{NH}_{2}\right)_{2} \mathrm{CO}$ would increase the crop yield. According to Lovatt et al. (1988), $\mathrm{NH}_{3}$ improves the induction of citrus flowering. Although $\mathrm{Ni}$ is essential for plant growth, its physiological role is poorly understood (Bai et al., 2008).

Methods of soil analysis to estimate Ni availability to plants are not routinely used in soil-fertility laboratories, in contrast to studies of other micronutrients. These methods focus on soil-fertility aspects and search for the correction of nutrient deficiencies as related to plant requirements for adequate growth. Universal extracting solutions may be used to simultaneously determine the soil availability of several nutrients in the same extract (Raij, 1994; Abreu et al., 1995; Eckert \& Watson, 1997). The availability of $\mathrm{P}, \mathrm{K}, \mathrm{Ca}, \mathrm{Mg}, \mathrm{Mn}, \mathrm{Cu}, \mathrm{Zn}$, $\mathrm{Mo}$, and $\mathrm{B}$ has been determined in multi-element extraction using Mehlich-3 solution (Mehlich, 1984; Sims, 1989; Jones Junior, 1990).

This work evaluated the urease activity in the leaves and the growth of lettuce plants in soil enriched with $\mathrm{Ni}$ and fertilized with urea and ammonium nitrate. Additionally, the Ni availability in the soil was evaluated using Mehlich-3 and DTPA extractors.

\section{MATERIAL AND METHODS}

\section{Plant growth}

Lettuce (Lactuca sativa L.) plants were grown in a Red-Yellow Brazilian Latosol in Viçosa, State of 
Minas Gerais. The experiment was conducted in a greenhouse of the Soil Science Department, Federal University of Viçosa. Soil samples collected in the 0$20 \mathrm{~cm}$ layer were air-dried, passed through a $2 \mathrm{~mm}$ sieve and analyzed for chemical and physical characterization (Table 1$)$. Nitrogen $\left(200 \mathrm{mg} \mathrm{dm}^{-3}\right)$ was supplied by two sources $\left(\mathrm{NH}_{4} \mathrm{NO}_{3}\right.$ and $\left.\mathrm{CO}\left(\mathrm{NH}_{2}\right)_{2}\right)$ and $\mathrm{Ni}$ (doses $0,2,4,8,12,16,24$, and $32 \mathrm{mg} \mathrm{dm}^{-3}$ $\mathrm{Ni}$ ) was supplied as $\mathrm{NiCl}_{2} \cdot 6 \mathrm{H}_{2} \mathrm{O}$. The experiment was arranged in a $2 \times 8$ factorial design with five replications in randomized blocks, and the experimental unit consisted of a $3 \mathrm{dm}^{3}$ plastic pot containing soil with the treatments and two lettuce plants. After liming to reach a $70 \%$ base saturation index (CFSEMG, 1999), the soil was incubated for 15 days maintaining soil moisture at field capacity. Each experimental unit received $300 \mathrm{mg} \mathrm{dm}^{-3} \mathrm{P}$ ( $\left.\mathrm{KH}_{2} \mathrm{PO} 4\right), 150 \mathrm{mg} \mathrm{dm}-3 \mathrm{~K}\left(\mathrm{~K}_{2} \mathrm{SO}_{4}\right), 2.5 \mathrm{mg} \mathrm{dm}^{-3} \mathrm{Fe}$ (Fe-EDTA), $3 \mathrm{mg} \mathrm{dm}^{-3} \mathrm{Mn}\left(\mathrm{MnCl}_{2} \cdot 4 \mathrm{H}_{2} \mathrm{O}\right), 4 \mathrm{mg} \mathrm{dm}^{-3}$ $\mathrm{Zn}\left(\mathrm{ZnSO}_{4} .7 \mathrm{H}_{2} \mathrm{O}\right), 1.0 \mathrm{mg} \mathrm{dm}{ }^{-3} \mathrm{Cu}\left(\mathrm{CuSO}_{4} .5 \mathrm{H}_{2} \mathrm{O}\right)$, $1.0 \mathrm{mg} \mathrm{dm}^{-3} \mathrm{~B}\left(\mathrm{H}_{3} \mathrm{BO}_{3}\right)$, and $0.15 \mathrm{mg} \mathrm{dm}^{-3} \mathrm{Mo}$ $\left(\mathrm{Na}_{2} \mathrm{MoO}_{4} \cdot 2 \mathrm{H}_{2} \mathrm{O}\right)$. The soil moisture was maintained at field capacity during plant growth. Nitrogen fertilization was split into two parts: the first (100 $\mathrm{mg} \mathrm{dm}^{-3}$ ) was applied prior to seedling transplanting, incorporated into the soil, and the second ( $100 \mathrm{mg} \mathrm{dm}^{-3}$ ) was divided into four $25 \mathrm{mg} \mathrm{dm}^{-3}$ portions that were broadcast on the soil surface, sequentially, every 10 days. Ur was applied in a mixture with a commercial product containing $2 \%$

Table 1. Red Yellow Latosol physical and chemical properties

\begin{tabular}{|c|c|}
\hline Property & Value \\
\hline $\mathrm{pH}\left(\mathrm{H}_{2} \mathrm{O}\right)(1: 2.5)$ & 4.80 \\
\hline Organic matter $\left(\text { dag } \mathrm{kg}^{-1}\right)^{(1)}$ & 3.00 \\
\hline $\left.\mathrm{P}(\mathrm{mg} \mathrm{dm})^{-3}\right)^{(2)}$ & 0.80 \\
\hline $\left.\mathrm{K}(\mathrm{mg} \mathrm{dm})^{-3}\right)^{(2)}$ & 24.0 \\
\hline $\mathrm{Al}^{3+}\left(\mathrm{cmol}_{\mathrm{c}} \mathrm{dm}^{-3}\right)^{(3)}$ & 0.20 \\
\hline $\mathrm{Ca}^{2+}\left(\mathrm{cmol}_{\mathrm{c}} \mathrm{dm}^{-3}\right)^{(3)}$ & 0.08 \\
\hline $\mathrm{Mg}^{2+}\left(\mathrm{cmol}_{\mathrm{c}} \mathrm{dm}^{-3}\right)^{(3)}$ & bdl \\
\hline $\mathrm{H}+\mathrm{Al}\left(\mathrm{cmol}_{\mathrm{c}} \mathrm{dm}^{-3}\right)^{(3)}$ & 4.80 \\
\hline $\mathrm{CEC}_{\mathrm{pH} 7.0}\left(\mathrm{cmol}_{\mathrm{c}} \mathrm{dm}^{-3}\right)^{(4)}$ & 7.04 \\
\hline Base saturation index $(\%)$ & 2.00 \\
\hline $\mathrm{Al}$ saturation index $(\%)$ & 58.80 \\
\hline $\left.\mathrm{Ni}(\mathrm{mg} \mathrm{dm})^{-3}\right)^{(2)}$ & bdl \\
\hline $\mathrm{Fe}\left(\mathrm{mg} \mathrm{dm}^{-3}\right)^{(2)}$ & 44.10 \\
\hline $\left.\mathrm{Zn}(\mathrm{mg} \mathrm{dm})^{-3}\right)^{(2)}$ & 0.26 \\
\hline $\left.\mathrm{Cu}(\mathrm{mg} \mathrm{dm})^{-3}\right)^{(2)}$ & 0.24 \\
\hline $\left.\operatorname{Mn}(\mathrm{mg} \mathrm{dm})^{-3}\right)^{(2)}$ & 3.60 \\
\hline Sand $(\%)^{(5)}$ & 22.00 \\
\hline $\operatorname{Silt}(\%)^{(5)}$ & 4.00 \\
\hline Clay $(\%)^{(5)}$ & 74.00 \\
\hline
\end{tabular}

${ }^{(1)}$ Walkley-Black method; ${ }^{(2)}$ Mehlich-1; ${ }^{(3)} \mathrm{KCl} 1 \mathrm{~mol} \mathrm{~L}^{-1}$; ${ }^{(4)} \mathrm{Ca}(\mathrm{OAc})_{2} 0.5 \mathrm{~mol} \mathrm{~L}-1$, pH 7.0 (Defelipo \& Ribeiro, 1981);

${ }^{(5)}$ Pipette (Embrapa, 1997); bdl: below detection limit. urease inhibitor $\mathrm{N}$-(n-butyl) thiophosphoric triamide (NBPT). The plants were harvested after 63 days of growth. From each experimental unit, the fresh matter of one plant was analyzed for determination of urease activity. The other plant was oven-dried at 65 ${ }^{\circ} \mathrm{C}$ for $72 \mathrm{~h}$, and the dry mass was recorded and the mineral composition determined.

The $\mathrm{N}$ concentration in the leaves was determined using the Kjeldhal method after sulfuric digestion, and the Ni leaf concentration by atomic emission spectroscopy (ICP/AES) after nitric-perchloric acid digestion (Zazoski \& Burau, 1977).

After the lettuce plants were cut, the soil from each pot was sampled, air-dried and passed through a $2 \mathrm{~mm}$ sieve. Soil Ni was extracted with Mehlich-3 (Mehlich, 1984) or DTPA (Raij et al., 2001), and the extracts were analyzed to determine $\mathrm{Ni}$ levels using atomic emission spectroscopy (ICP/AES).

\section{Urease activity on leaves}

The phenol hypochlorite assay of Witte \& MedinaEscobar (2001), with modifications of the reaction time and temperature to $2 \mathrm{~h}$ and $40^{\circ} \mathrm{C}$, respectively, was used to analyze the urease activity in the lettuce-leaf extracts. The reagents used for the assay were a solution of $50 \mathrm{mmol} \mathrm{L}^{-1}$ phosphate buffer (PBS), Reagent A and Reagent $\mathrm{B}$. The $50 \mathrm{mmol} \mathrm{L}^{-1}$ phosphate buffer solution (PBS) was prepared with $3.403 \mathrm{~g}$ $\mathrm{KH}_{2} \mathrm{PO}_{4}$ and $4.355 \mathrm{~g} \mathrm{~K}_{2} \mathrm{HPO}_{4}$ dissolved in $400 \mathrm{~mL}$ distilled water, with additional water added for a final volume of $1 \mathrm{~L}$, and the $\mathrm{pH}$ was adjusted to 7.5. Reagent A was prepared with $34 \mathrm{mg}$ of $\mathrm{Na}_{2}\left[\mathrm{Fe}(\mathrm{CN})_{5} \mathrm{NO}\right] \cdot 2 \mathrm{H}_{2} \mathrm{O}$ (disodium pentacyanonitrosylferrate) and $7 \mathrm{~g}$ of $\mathrm{C}_{6} \mathrm{H}_{5} \mathrm{OH}$ (phenol) dissolved in $80 \mathrm{~mL}$ distilled water, completing the volume to $100 \mathrm{~mL}$ (stored in a dark flask at $4^{\circ} \mathrm{C}$ ). Reagent $\mathrm{B}$ was prepared with $2.96 \mathrm{~g}$ of $\mathrm{NaOH}$ dissolved in $140 \mathrm{~mL}$ distilled water plus $22.26 \mathrm{~g}$ of $\mathrm{Na}_{2} \mathrm{HPO}_{4}$ and $40 \mathrm{~mL} \mathrm{NaOCl}(6 \%)$, completing the volume to $200 \mathrm{~mL}$, with the $\mathrm{pH}$ adjusted to 12 (stored in a dark flask at room temperature).

For protein extraction, discs collected from six fresh lettuce leaves (two from the lower portion of the plant, two from the top, and two from the middle) were ground and homogenized in a Petri plate. Samples of $1.0 \mathrm{~g}$ were ground in a previously cooled mortar with $5 \mathrm{~mL}$ of PBS, plus $120 \mu \mathrm{L}$ of $825 \mathrm{mmol} \mathrm{L}^{-1}$ dithiothreitol (DDT), plus $20 \mu \mathrm{L}$ of $26 \mathrm{mmol} \mathrm{L}^{-1}$ phenylmethylsulfonyl fluoride (PMSF) (in ethylic alcohol) plus $30 \mathrm{mg}$ of polyvinylpolypyrrolidone (PVPP). After extraction, the samples were placed in Eppendorf tubes and centrifuged at $14.000 \mathrm{~g}$ for $10 \mathrm{~min}$ at $4{ }^{\circ} \mathrm{C}$. The supernatant was collected, transferred into new tubes and centrifuged again at $14.000 \mathrm{~g}$ for $20 \mathrm{~min}$ at $4^{\circ} \mathrm{C}$. After the final centrifugation, the extract, a clear protein solution, was removed and kept on ice to determine the urease activity.

To identify the adequate time of reaction in the phenol hypochlorite assay (Witte \& Medina-Escobar, 2001), preliminary tests were performed with the 
lettuce-leaf extracts after $1.0,1.5,2.0,2.5$, and $3.0 \mathrm{~h}$ of reaction. The absorbance was measured at $636 \mathrm{~nm}$, and the absorbance readings were plotted as a function of the reaction times.

For urease-activity analysis, $20 \mu \mathrm{L}$ of $5 \mathrm{~mol} \mathrm{~L}^{-1}$ urea was added to a test tube containing $180 \mu \mathrm{L}$ of leaf extract, and the tube was shaken and placed to heat in a water bath for $2 \mathrm{~h}$ at $40^{\circ} \mathrm{C}$ (heated extract). To $20 \mu \mathrm{L}$ of heated extract, $980 \mu \mathrm{L}$ distilled water, $100 \mu \mathrm{L}$ of Reagent A and $200 \mu \mathrm{L}$ of Reagent B were added. The tubes were sealed and placed in a water bath for $20 \mathrm{~min}$ at $50^{\circ} \mathrm{C}$ to reach the endpoint of color development. The absorbance was read at $636 \mathrm{~nm}$, and the urease activities in the leaf extracts were calculated. The results were expressed in katal (kat), a unit of the International System of Units for enzyme activity. One katal (1 kat) is the amount of enzyme required for transformation of $1 \mathrm{~mol} \mathrm{~s}^{-1}$ of substrate at defined conditions (Dybkaer, 2001). Standards of $\mathrm{NH}_{4} \mathrm{Cl}$ were prepared at $0,4,10,20,40$, and $80 \mu \mathrm{mol} \mathrm{L}-1$ concentrations and assayed as described for the leaf extracts.

\section{Statistics}

Analyses of variance were conducted for the lettuce plants dry-matter yield, leaf urease activity, shoot $\mathrm{Ni}$ and $\mathrm{N}$ concentrations and $\mathrm{Ni}$ levels extracted from soil using Mehlich-3 (M-3) and DTPA.

Regression equations were adjusted for the drymatter yield of lettuce shoots and the concentrations and contents of $\mathrm{Ni}$ in the shoots as a function of the doses of $\mathrm{Ni}$ applied to soil, within each $\mathrm{N}$ source (AN and Ur). The regression equations were adjusted for urease activity in the fresh matter of the lettuce leaves as a function of the Ni doses applied to soil, within each $\mathrm{N}$ source (AN and Ur).

The software SAEG (Statistical Analysis System) (Ribeiro Jr., 2001) was used for the statistical analysis.

\section{RESULTS AND DISCUSSION}

\section{Plant growth}

The lettuce dry-matter yield was greater in the plants supplied with $\mathrm{NH}_{4} \mathrm{NO}_{3}(\mathrm{AN})(5.07 \mathrm{~g} /$ plant $)$ than in the plants supplied with $\left(\mathrm{NH}_{2}\right)_{2} \mathrm{CO}$ (Ur) $(4.20 \mathrm{~g} /$ plant) (Figure 1, Tables 2 and 3). Vitti et al. (2002) found similar results for sugarcane in the field, with a yield of $66 \mathrm{t} \mathrm{ha}^{-1}$ for plants supplied with N-AN and of $57 \mathrm{t} \mathrm{ha}^{-1}$ when supplied with N-Ur. Gerendás \& Sattelmacher (1997b) observed improved growth of zucchini plants in a nutrient solution containing AN, compared to plants supplied with Ur as N source.

There was no response in lettuce growth to the addition of $\mathrm{Ni}$ to soil, regardless of the $\mathrm{N}$ source, be it AN or Ur (Figure 1, Table 2). Similarly, in a nutrient solution, rye did not respond to increased doses of $\mathrm{Ni}$;

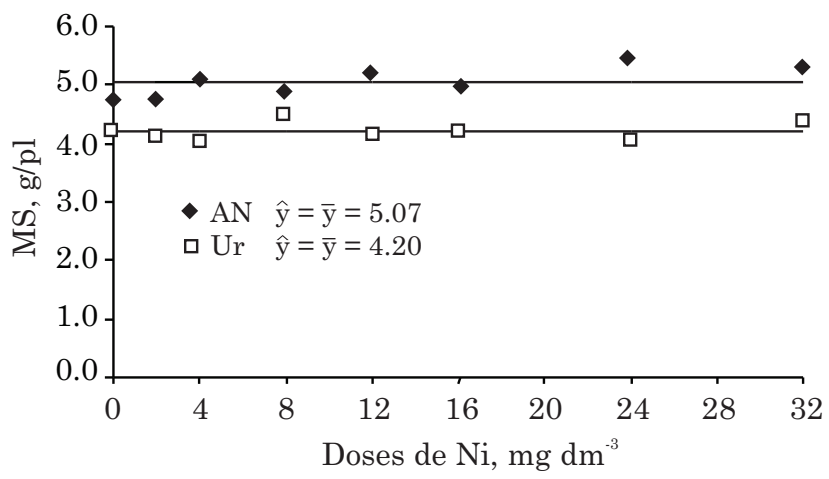

Figure 1. Lettuce dry-matter (DM) shoot production as a function of $\mathrm{Ni}$ doses applied to the soil and under plant $N$ supply by additions of ammonium nitrate (AN) and urea (Ur) to the soil.

however, the dry-matter yield of soybean, cucumber and sunflower plants increased (Gerendás \& Sattelmacher, 1997a). The shoots of plants grown in soil without $\mathrm{Ni}\left(0.0 \mathrm{mg} \mathrm{dm}^{-3}\right.$ treatment) contained $0.75 \mathrm{mg} \mathrm{kg}^{-1} \mathrm{Ni}$ when treated with $\mathrm{AN}$ and $0.19 \mathrm{mg} \mathrm{kg}^{-1}$ $\mathrm{Ni}$ when $\mathrm{Ur}$ was the $\mathrm{N}$ source (Table 2). The plant growth without Ni supply was similar to the plant growth in all treatments with $\mathrm{Ni}$ soil application (Figure 1). This pattern shows that the Ni levels added to the soil had no effect on lettuce growth, and although no available $\mathrm{Ni}$ (based on Mehlich-1 extraction) in the soil was detected (Table 1), no Ni deficiency was observed in the plants. Because it is unlikely that $\mathrm{Ni}$ in the lettuce seeds $(0.45 \mathrm{ng} /$ seeds $)$ provided adequate $\mathrm{Ni}$ for growth, the inputs used in the soil treatment may have contributed to supply the plants with Ni. Gerendás \& Sattelmacher $(1997 \mathrm{a}, \mathrm{b})$ reported that experiments investigating Ni deficiency in nutrient solutions require special care to remove $\mathrm{Ni}$ from the growth medium, with the mandatory use of highpurity chemicals and a rigorous cleaning of all equipment. Whereas Ni deficiency is not commonly reported in plants, toxicity is the focus of many studies, mainly in sludge-treated soils.

\section{Urease activity}

The $2 \mathrm{~h}$ reaction time used for the urease-activity determination in the leaf extracts was based on results of preliminary tests, which showed a linear relationship between the absorbance readings (at 636 $\mathrm{nm}$ ) and reaction times tested at $40^{\circ} \mathrm{C}$ (Figure 2). This linear behavior for the relationship between $\mathrm{NH}_{3}$ production and time spent for the occurrence of the enzymatic reaction is a criterion to ensure that no agents are interfering with the reaction medium (Witte \& Medina-Escobar, 2001).

The leaf urease activity increased as a function of the increment of $\mathrm{Ni}$ applied to soil, independently of whether AN or Ur was used (Figure 3, Table 2). This activity increase was strong up to the concentration of $2 \mathrm{mg} \mathrm{dm}^{-3} \mathrm{Ni}$, less evident at the higher $\mathrm{Ni}$ levels and remained practically unchanged at concentrations 
Table 2. Nickel $(\mathrm{Ni})$ and nitrogen $(\mathrm{N})$ concentrations in the dry matter of lettuce plants grown in soil amended with $\mathrm{Ni}$ doses and fertilized with two $\mathrm{N}$ sources. The regression equations for the dry-matter $\mathrm{Ni}$ and $\mathrm{N}$ are functions of the Ni doses applied to the soil

\begin{tabular}{|c|c|c|c|c|c|c|c|c|}
\hline \multirow{2}{*}{$\mathbf{N}$ source } & \multicolumn{8}{|c|}{ Ni doses $\left(\mathrm{mg} \mathrm{dm}^{-3}\right)$} \\
\hline & $\mathbf{0}$ & 2 & 4 & 8 & 12 & 16 & 24 & 32 \\
\hline \multicolumn{9}{|c|}{$\mathrm{Ni}\left(\mathrm{mg} \mathrm{kg}^{-1}\right)$} \\
\hline $\mathrm{NH}_{4} \mathrm{NO}_{3}$ & 0.75 & 1.28 & 2.02 & 3.93 & 5.5 & 7.16 & 11.08 & 13.67 \\
\hline & \multicolumn{8}{|c|}{$\hat{y}=0.5432+0.4188^{* * *} x \quad R^{2}=0.99$} \\
\hline \multirow{3}{*}{$\left(\mathrm{NH}_{2) 2} \mathrm{CO}\right.$} & 0.19 & 1.20 & 2.05 & 3.54 & 5.17 & 6.24 & 9.59 & 11.75 \\
\hline & \multicolumn{8}{|c|}{$\hat{\mathrm{y}}=0.5275+0.3625^{* * * x} \quad R^{2}=0.99$} \\
\hline & & & & $\mathrm{N}$ tot & $\left.\mathrm{kg}^{-1}\right)$ & & & \\
\hline \multirow[t]{2}{*}{$\mathrm{NH}_{4} \mathrm{NO}_{3}$} & 3.68 & 3.61 & 3.70 & 3.76 & 3.49 & 3.76 & 3.49 & 3.48 \\
\hline & \multicolumn{8}{|c|}{$\hat{y}=\bar{y}=3.60$} \\
\hline \multirow[t]{2}{*}{$\left(\mathrm{NH}_{2}\right)_{2} \mathrm{CO}$} & 3.99 & 4.04 & 3.90 & 4.00 & 4.06 & 3.95 & 4.00 & 3.91 \\
\hline & \multicolumn{8}{|c|}{$\hat{\mathrm{y}}=\overline{\mathrm{y}}=4.00$} \\
\hline
\end{tabular}

Table 3. Analysis of variance for plant dry-matter yield (DMY), leaf urease activity (LUrA), Ni and N concentrations in lettuce, and Ni extracted from the soil with Mehlich-3 (M-3) and DTPA

\begin{tabular}{|c|c|c|c|c|c|c|c|}
\hline \multirow{2}{*}{ Source of variation } & \multirow{2}{*}{ DF } & \multicolumn{6}{|c|}{ MS } \\
\hline & & DMY & LUrA & $\mathbf{N i}$ & $\mathbf{N}$ & M-3 & DTPA \\
\hline & & \multicolumn{4}{|c|}{ - plant - } & \multicolumn{2}{|c|}{$-\mathrm{Ni}$ (soil) } \\
\hline Blocks & 4 & $1.89^{\text {ns }}$ & $1,743.50^{* * * *}$ & $3.88^{* *}$ & $0.14^{\mathrm{ns}}$ & $0.81^{\mathrm{ns}}$ & $1.37^{\mathrm{ns}}$ \\
\hline $\mathrm{N}$ sources & 1 & $15.31^{* * * *}$ & $1,115.50^{\mathrm{ns}}$ & $9.93^{* *}$ & $2.98^{* * * *}$ & $5.72^{* * *}$ & $6.18^{*}$ \\
\hline Ni within $\mathrm{AN}$ & 7 & $0.28^{\mathrm{ns}}$ & $1,782.30^{* * *}$ & $110.99^{* * *}$ & $0.06^{\mathrm{ns}}$ & $83.94^{* * *}$ & $30.74^{* * * *}$ \\
\hline Ni within $\mathrm{Ur}$ & 7 & $0.11^{\mathrm{ns}}$ & $2,175.30^{* * * *}$ & $83.26^{* * * *}$ & $0.02^{\text {ns }}$ & $76.53^{\text {**** }}$ & $20.52^{* * * *}$ \\
\hline Residue & 60 & 0.95 & 197.30 & 0.92 & 0.07 & 0.79 & 1.28 \\
\hline $\mathrm{CV}(\%)$ & & 20.10 & 21.80 & 18.03 & 7.21 & 20.58 & 46.49 \\
\hline
\end{tabular}

ns, $* *$ and $* * *$ : not significant and significant at 1 and $0.1 \%$, respectively.

of over $8 \mathrm{mg} \mathrm{dm}^{-3} \mathrm{Ni}$. There was no difference in the leaf urease-activity responses to AN and Ur (Figure 3 , Table 2). In the plants supplied with $\mathrm{AN}$, the maximum urease activity $\left(1.35 \mu \mathrm{kat} \mathrm{kg}^{-1}\right.$ in the fresh matter) was reached with $18.40 \mathrm{mg} \mathrm{dm}^{-3}$ soil Ni, whereas with Ur, the maximum was $1.42 \mu \mathrm{kat} \mathrm{kg}^{-1}$ for $20.40 \mathrm{mg} \mathrm{dm}^{-3}$ soil Ni (Figure 3). The $18.40 \mathrm{mg} \mathrm{dm}^{-3}$ and $20.40 \mathrm{mg} \mathrm{dm}^{-3} \mathrm{Ni}$ doses corresponded to plant $\mathrm{Ni}$ concentrations equal to $8.25 \mathrm{mg} \mathrm{kg}^{-1}$ for the AN treatment and $7.92 \mathrm{mg} \mathrm{kg}^{-1}$ for Ur, respectively. These $\mathrm{Ni}$ concentrations in leaves are in the 1 to $10 \mathrm{mg} \mathrm{kg}^{-1}$ range (Marschner, 2008) found for $\mathrm{Ni}$ in the vegetative tissues of most plants. Krogmeier et al. (1991) found increased soybean-leaf urease activity in response to $\mathrm{Ni}$, which controlled the absorption of the foliar-applied urea, preventing urea accumulation in the leaves.

\section{Plant $\mathbf{N i}$ and $\mathbf{N}$}

For both $\mathrm{N}$ sources (AN and Ur), the Ni level in the shoots increased linearly in response to the $\mathrm{Ni}$ applied to the soil, with higher values found in the plants on soil supplied with AN (Tables 2 and 3). For most of the plants, the leaf Ni concentrations (Table 2) were below $10 \mathrm{mg} \mathrm{kg}^{-1}$, which is the phytotoxic limit for sensitive species (Marschner, 2008). In the plants supplied with 24 and $32 \mathrm{mg} \mathrm{dm}^{-3} \mathrm{Ni}(\mathrm{AN})$ and $32 \mathrm{mg} \mathrm{dm}^{-3} \mathrm{Ni}(\mathrm{Ur})$, the $\mathrm{Ni}$ concentrations in leaves were $11.08,13.67$ and $11.75 \mathrm{mg} \mathrm{kg}^{-1}$, respectively (Table 2). These values are above the $10 \mathrm{mg} \mathrm{kg}^{-1}$ toxicity limit but below $50 \mathrm{mg} \mathrm{kg}^{-1} \mathrm{Ni}$, which is the limit for moderately tolerant species (Marschner, 2008). Fontes et al. (2008) observed lettuce leaves with 4.7 $\mathrm{mg} \mathrm{kg}^{-1} \mathrm{Ni}$ in a clayey Latosol (73\% clay) amended with $32 \mathrm{mg} \mathrm{dm}^{-3} \mathrm{Ni}$, whereas in a sandy Latosol $(70 \%$ sand), the leaf $\mathrm{Ni}$ concentration was $40.0 \mathrm{mg} \mathrm{kg}^{-1}$. Here, the soil clay content was $74 \%$ (Table 1 ), and the average leaf $\mathrm{Ni}$ concentrations in the $\mathrm{AN}$ and $\mathrm{Ur}$ treatments were $12.7 \mathrm{mg} \mathrm{kg}^{-1}$ (Table 2), which is closer to the Ni leaf concentrations found by Fontes et al. (2008) in a clayey soil. According to Marschner (2008), the $\mathrm{Ni}$ concentration range in the vegetative tissues of most plants is between 1 and $10 \mathrm{mg} \mathrm{kg}^{-1}$ and 


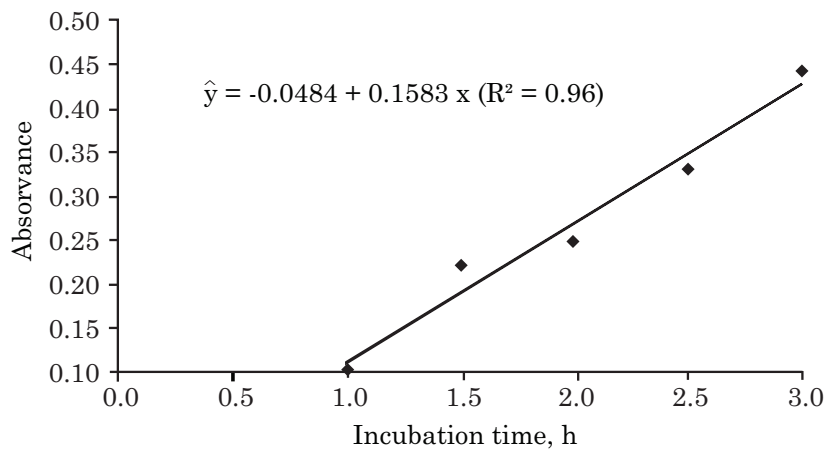

Figure 2. Absorbance (at $636 \mathrm{~nm}$ ) due to $\mathrm{NH}_{3}$ production (mediated by urease activity) in lettuce-leaf extracts as a function of the reaction periods (incubation time, IT) for $\mathrm{NH}_{3}$ production at $40{ }^{\circ} \mathrm{C}$.

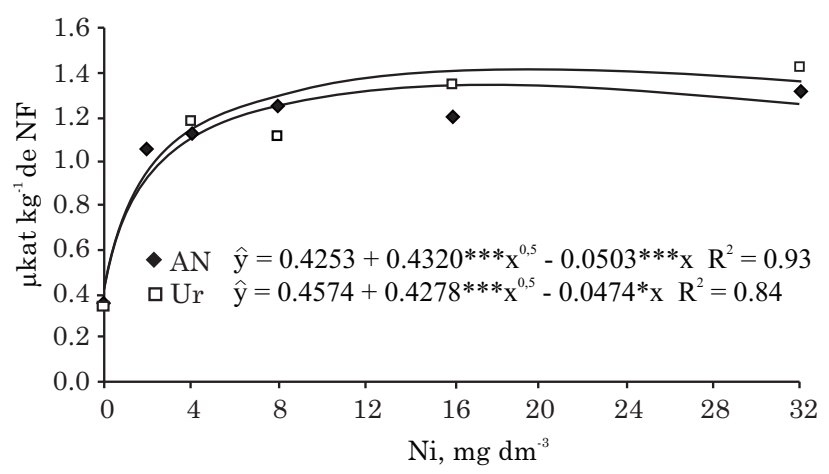

Figure 3. Urease activity in the fresh matter (FM) of lettuce leaves as a function of $\mathrm{Ni}$ doses added to soil fertilized with $\mathbf{N}$ supplied as ammonium nitrate (AN) and urea (Ur).

expresses the plant characteristics related to the efficiency of absorption and transport from roots to shoots. The Ni lettuce leaf concentration of $12.7 \mathrm{mg} \mathrm{kg}^{-1}$ (average of plants treated with $32 \mathrm{mg} \mathrm{dm}^{-3}$ soil-applied $\mathrm{Ni}$ in either AN or Ur as $\mathrm{N}$ source) in a soil with $74 \%$ clay (high cation-retention capacity) indicates the efficiency of lettuce for $\mathrm{Ni}$ uptake and translocation. It is important to note that no Ni-toxicity symptoms were observed in the plants.

The $\mathrm{N}$ concentrations in the leaves of the plants from the Ur treatments were higher than those in the treatments with AN (Tables 2 and 3). The ureaseinhibitor application assured the persistence of $\mathrm{N}$ in the soil, making $\mathrm{N}$ available for root absorption. Nitrogen loss from urea occurs through $\mathrm{NH}_{3}$ volatilization due to urea enzymatic hydrolysis ( Da Ros et al., 2005), a reaction mediated by urease and intensified when urea is spread on the soil surface. Because the dry-matter yield was greater in the plants supplied with AN (Figure 1), it seems that some adverse effect occurred in the treatments with Ur application. Similarly, in zucchini plants grown in a nutrient solution supplied with different $\mathrm{N}$ sources, plant dry weight in AN treatments was greater than under Ur supply (Gerendás \& Sattelmacher, 1997b).

Regarding the plant response to $\mathrm{Ni}$ soil application, the shoot $\mathrm{N}$ concentrations varied little in the treatments with $\mathrm{AN}$ and Ur, varying from 3.5 to $3.8 \mathrm{dag} \mathrm{kg}^{-1}$ for AN and from 3.9 to $4.1 \mathrm{dag} \mathrm{kg}^{-1}$ for Ur (Table 2). These values are in agreement with the optimum range for $\mathrm{N}$ concentration (2.0-5.0 dag kg-1) in lettuce leaves in the pre-harvest growth period (Hochmuth et al., 1991; Jones Junior et al., 1991; Ludwick, 2002; Hartz \& Jonhstone, 2007).

\section{Ni in soil}

Lindsay \& Norvell (1978) and Whitney (1988) used Mehlich-3 and DTPA extractors for the extraction of cationic micronutrients $\left(\mathrm{Fe}^{2+}, \mathrm{Mn}^{2+}, \mathrm{Zn}^{2+}\right.$ and $\left.\mathrm{Cu}^{2+}\right)$ from the soil. Here, the Ni concentrations extracted with Mehlich-3 and DTPA increased linearly as a function of the $\mathrm{Ni}$ applied to soil (Table 3). The Mehlich-3 approach recovered more Ni than DTPA (Table 3) because DTPA (calcium chloride and triethanolamine) removes $\mathrm{Ni}$ only by forming complexes, whereas Mehlich-3 (acetic acid, ammonium nitrate, nitric acid, ammonium fluoride and EDTA) additionally removes $\mathrm{Ni}$ by exchange reactions. The efficiency of Ni-extraction methods for the analysis of soil $\mathrm{Ni}$ availability to plants on a routine basis is still a matter of study. The efficiency of Mehlich-3 for the determination of soil Ni availability for tobacco (Mulchi et al., 1991), common bean (Abreu et al., 1995), sorghum (Revoredo \& Mello, 2006), and lettuce and common bean (Fontes et al., 2008) has been reported. For DTPA soil extraction, the $\mathrm{Ni}$ recovered from soil correlated with $\mathrm{Ni}$ in corn leaves (Oliveira, 1995) and with $\mathrm{Ni}$ in the leaves and grains of common bean (Berton et al., 2006). Here, the Ni concentrations recovered by DTPA and M-3 were correlated with the Ni concentrations and contents in lettuce shoots (Table 5), indicating the efficiency of these extractors for Ni analysis in the Red-Yellow Latosol studied.

In the soil treated with $\mathrm{AN}$, the $\mathrm{Ni}$ levels recovered with M-3 and DTPA were higher than the levels in the Ur-treated soil (Tables 3 and 4). Urea hydrolysis generates $\mathrm{NH}_{3}$ (Mulrooney \& Hausinger, 2003), which may be lost by volatilization. It seems that $\mathrm{NH}_{3}$ loss contributed to decrease the $\mathrm{NH}_{4}{ }^{+}$ concentration in the Ur-treated soil, lowering the competition with $\mathrm{Ni}^{2+}$ for soil adsorption sites and allowing greater $\mathrm{Ni}^{2+}$ adsorption. In contrast, a higher $\mathrm{NH}_{4}{ }^{+}$concentration in the $\mathrm{AN}$-treated soil increased the competition with $\mathrm{Ni}^{2+}$, forcing its release from the soil exchange sites. A high soil clay content $\left(74 \%\right.$ ) (Table 1 ) magnified the $\mathrm{Ni}^{2+}$-adsorption effect. In addition to the absence of $\mathrm{NH}_{4}{ }^{+}$competition in Ur-treated soil, Ni utilization by microorganisms 
Table 4. Nickel concentrations in soil amended with $\mathrm{Ni}$ and fertilized with two $\mathrm{N}$ sources. Regression equations for the Ni recovered from the soil (Mehlich-3 and DTPA extractions) are a function of the Ni doses applied to the soil

\begin{tabular}{|c|c|c|c|c|c|c|c|c|}
\hline \multirow{2}{*}{ N source } & \multicolumn{8}{|c|}{ Ni doses $\left(\mathrm{mg} \mathrm{dm}^{-3}\right)$} \\
\hline & $\mathbf{0}$ & 2 & 4 & 8 & 12 & 16 & 24 & 32 \\
\hline & \multicolumn{8}{|c|}{$-\mathrm{mg} \mathrm{dm} \mathrm{m}^{-3}$} \\
\hline & \multicolumn{8}{|c|}{ Ni recovered (Mehlich-3) } \\
\hline \multirow[t]{2}{*}{$\mathrm{NH}_{4} \mathrm{NO}_{3}$} & 0.00 & 0.78 & 1.17 & 3.17 & 5.19 & 6.01 & 8.73 & 11.57 \\
\hline & \multicolumn{8}{|c|}{$\hat{\mathrm{y}}=0.1233+0.3635^{* * * \mathrm{x}} \quad \mathrm{R}^{2}=0.99$} \\
\hline \multirow[t]{3}{*}{$\left(\mathrm{NH}_{2) 2} \mathrm{CO}\right.$} & 0.00 & 0.33 & 1.36 & 2.28 & 4.17 & 5.04 & 8.10 & 11.06 \\
\hline & \multicolumn{8}{|c|}{$\left.\hat{\mathrm{y}}=-0.2173+0.3477^{* * * *} \mathrm{x} \quad \mathrm{R}^{2}=0.99\right)$} \\
\hline & & & & Ni reco & DTPA) & & & \\
\hline \multirow[t]{2}{*}{$\mathrm{NH}_{4} \mathrm{NO}_{3}$} & 0.00 & 0.49 & 0.76 & 1.83 & 2.73 & 3.51 & 5.46 & 6.95 \\
\hline & \multicolumn{8}{|c|}{$\hat{\mathrm{y}}=0.00138+0.2205^{* * * x} \quad \mathrm{R}^{2}=0.99$} \\
\hline \multirow[t]{2}{*}{$\left(\mathrm{NH}_{2}\right)_{2} \mathrm{CO}$} & 0.00 & 0.34 & 0.79 & 1.30 & 2.19 & 2.55 & 4.26 & 5.84 \\
\hline & \multicolumn{8}{|c|}{$\hat{y}=-0.0443+0.1799^{* * * x} \quad R^{2}=0.99$} \\
\hline
\end{tabular}

Table 5. Linear coefficients for the correlations between Ni contents and concentrations in the lettuce shoots and the concentrations recovered from the soil with DTPA and Mehlich-3

\begin{tabular}{|c|c|c|}
\hline Extractor & Ni shoot & Ni contents \\
\hline & \multicolumn{2}{|c|}{ Ammonium Nitrate } \\
\hline \multirow[t]{3}{*}{ Mehlich-3 } & $0,91 *$ & $0,83^{*}$ \\
\hline & $0,79 *$ & $0,72^{*}$ \\
\hline & \multicolumn{2}{|c|}{ Urea } \\
\hline \multirow[t]{2}{*}{ DTPA } & $0,97 *$ & $0,95^{*}$ \\
\hline & $0,96 *$ & $0,94 *$ \\
\hline
\end{tabular}

Significant at $5 \%$ based on a $t$-test.

in the synthesis of urease required for Ur breakdown may have contributed to the lower Ni extraction from the Ur-treated soil.

\section{CONCLUSIONS}

1. Nickel additions to the soil in the range of 0.0 to $32 \mathrm{mg} \mathrm{dm}^{-3}$ had no effect on lettuce growth in soil fertilized with AN or Ur, and no toxicity symptoms were observed.

2. The urease activity in lettuce leaves had a quadratic response to the addition of $\mathrm{Ni}$ to soil.

3. There was no difference between the urease activity in the leaves of lettuce grown in soil fertilized with AN or Ur.

4. With $\mathrm{AN}$ and $\mathrm{Ni}$ additions to soil (from 0.0 to $32 \mathrm{mg} \mathrm{dm}^{-3}$ ), the maximum lettuce-leaf urease activity was reached with $18.40 \mathrm{mg} \mathrm{dm}^{-3} \mathrm{Ni}$. With Ur fertilization, this maximum activity was reached with $20.40 \mathrm{mg} \mathrm{dm}^{-3} \mathrm{Ni}$.

\section{ACKNOWLEDGEMENTS}

The authors thank the FAPEMIG (Fundação de Amparo à Pesquisa do Estado de Minas Gerais) for financial support and scholarship for the first author and CNPq (Conselho Nacional de Desenvolvimento Científico e Tecnológico) for the research fellowship to Renildes L.F. Fontes.

\section{LITERATURE CITED}

ABREU, C.A.; ABREU, M.F.; RAIJ, B.van \& SANTOS, W.R. Comparação de métodos de análise para avaliar a disponibilidade de metais pesados em solos. R. Bras. Ci. Solo, 19:463-468, 1995.

BAI, C.; REILLY, C.C. \& WOOD, B.W. Nickel deficiency disrupts metabolism of ureides, amino acids, and organic acids of young pecan foliage. Plant Physiol., 140:433-443, 2006.

BAI, C.; WOOD, B.W. \& REILLY, C.C. Insights into nutritional physiology of nickel. Acta Hortic., 772:365-368. 2008.

BERTON, R.S.; PIRES, A.M.M.; ANDRADE, S.A.L.; ABREU, C.A.A.; AMBROSINO, E.J. \& SILVEIRA, A.P.D. Toxicidade do níquel em plantas de feijão e efeitos sobre a microbiota do solo. Pesq. Agropec. Bras., 41:1305-1312, 2006 . 
BROWN, P.H.; WELCH, R.M. \& CARY, E.E. Nickel: A micronutrient essential for higher plants. Plant Physiol., 85:801-803, 1987.

COMISSÃO DE FERTILIDADE DO SOLO DO ESTADO DE MINAS GERAIS - CFSEMG. Recomendação de calagem e adubação para o estado de Minas Gerais. 5.ed. Viçosa, MG, Universidade Federal de Viçosa, 1999. 359p.

Da ROS, C.O.; AITA, C. \& GIACOMINI, S.J. Ammonium volatilization in the application of urea on the soil surface in the no-tillage system. Ci. Rural, 35:799-805, 2005.

DEFELIPO, B.V. \& RIBEIRO, A.C. Análise química do solo: Metodologia. Viçosa, MG, Universidade Federal de Viçosa, 1981. 71p. (Boletim de Extensão, 29)

DYBKAER, R. Unit "katal" for catalytic activity. Pure Appl. Chem., 73:927-931, 2001.

DIXON, N.E.; GAZOLA, C.; BLAKELEY, R.L. \& ZERNER, B. Jack bean urease (EC 3.5.1.5), a metalloenzyme. A simple biological role for nickel? J. Am. Chem. Soc., 97:41314133, 1975

EMPRESA BRASILEIRA DE PESQUISA AGROPECUÁRIA EMBRAPA. Centro Nacional de Pesquisa de Solos. Manual de métodos de análise de solo. Rio de Janeiro, 1997. $212 p$.

ECKERT, D.J. \& WATSON, M.E. Integrating the Mehlich-3 extractant into existing soil test interpretation schemes. In: HOOD, T.M. \& JONES, J.B., eds. Soil and plant analysis in sustainable agriculture and environment. New York, Marcel Dekker, 1997. p.239-251.

ESKEW, D.L.; WELCH, R.M. \& CARY, E.E. Nickel: An essential micronutrient for legumes and possibly all higher plants. Science, 222:621-623, 1983.

ESKEW, D.L.; WELCH, R.M. \& NORVELL, W.A. Nickel in higher plants. Further evidence for an essential role. Plant Physiol., 76:691-693, 1984.

FONTES, R.L.F.; PEREIRA, J.M.N.; NEVES, J.C.L. \& FONTES, M.P.F. Cadmium, lead, copper, zinc and nickel in lettuce and dry beans as related to Mehlich-3 extraction in three Brazilian Latossols. J. Plant Nutr., 31:884-901, 2008.

GERENDÁS, J. \& SATTELMACHER, B. Significance of Ni supply for growth, urease activity and the concentrations of urea, amino acids and mineral nutrients of urea-grown plants. Plant Soil, 190:153-162, 1997a.

GERENDÁS, J. \& SATTELMACHER, B. Significance of N source (urea versus $\mathrm{NH}_{4} \mathrm{NO}_{3}$ ) and $\mathrm{Ni}$ supply for growth, urease activity and nitrogen metabolism of zucchini (Cucurbita pepo). Plant Soil, 196:217-222, 1997b.

GERENDÁS, J.; ZHU, Z. \& SATTELMACHER, B. Influence of $\mathrm{N}$ and $\mathrm{Ni}$ supply on nitrogen metabolism and urease activity in rice (Oryza sativa L.). J. Exp. Bot., 49:1545$1554,1998$.

HARTZ, T.K. \& JOHNSTONE, P.R. Establishing lettuce leaf nutrient optimum ranges through DRIS Analysis. Hortscience, 42:143-146, 2007.
HOCHMUTH, G.; MAYNARD, D.; VAVRINA, C. \& HANLON, E. Plant tissue analysis and interpretation for vegetable crops in Florida. Gainesville, University Florida, 1991. (Special Publication. SS-VEC-42)

JONES JUNIOR, J.B. Universal soil extractants: Their composition and use. Commun. Soil Sci. Plant Anal., 21:1091-1101, 1990.

JONES JUNIOR, J.B.; WOLF, B. \& MILLS, H.A. Plant analysis handbook. Athens, Micro-Macro Publishing, 1991. 213p.

KLUCAS, R.V.; HANUS, F.J.; RUSSEL, S.A. \& EVANS, H.J. Nickel: A micronutrient element for hydrogen-dependent growth of Rhizobium japonicum and for expression of urease activity in soybean leaves. Proc. Nat. Acad. Sci. USA, 80:2253-2257, 1983.

KOPITTKE, P.M.; ASHER, C.J. \& MENZIES, N.W. Toxic effects of $\mathrm{Ni}^{2+}$ on growth of cowpea (Vigna unguiculata). Plant Soil, 292:283-289, 2007.

KROGMEIER, M.J.; McCARTY, G.W.; SHOGREN, D.R. \& BREMNER, J.M. Effect of nickel deficiency in soybean on the phytotoxicity of foliar-applied urea. Plant Soil, 135:283-286, 1991.

LINDSAY, W.L.; NORVELL, W.A. Development of DTPA soil test for zinc, iron, manganese and copper. Soil Sci. Soc. Am. J., 42:421-428, 1978.

LOVATT, C.J.; ZHENG, Y. \& HAKE, K.D. Demonstration of a change in nitrogen metabolism influencing flower initiation in citrus. Israel J. Bot., 37:181-188, 1988.

LUDWICK, A.E., ed. Western fertilizer handbook. 9.ed. Danville, Interstate Publishers, 2002. 356p.

MALAVOLTA, E.; LEÃO, H.C.; OLIVEIRA, S.C.; LAVRES JUNIOR, J.; MORAES, M.F.; CABRAL, C.P. \& MALAVOLTA, M. Repartition of nutrients in citrus, flowers, leaves and branches. R. Bras. Frutic., 28:506$511,2006$.

MARSCHNER, H. Mineral nutrition of higher plants. 3.ed. London, Academic Press, 2008. 889p.

MEHLICH, A. Mehlich 3 soil test extractant: A modification of Mehlich 2 extractant. Commun. Soil Sci. Plant Anal., 15:1409-1416, 1984.

MULCHI, C.L.; ADAMU, C.A.; BELL, P.F. \& CHANEY, R.L. Residual heavy metal concentrations in sludge-amended Coastal Plain soils: 1. Comparison of extractants. Commun. Soil Sci. Plant Anal., 22:919-941, 1991.

MULROONEY, S.B. \& HAUSINGER, R.P. Nickel uptake and utilization by microorganisms. FEMS Microbiol. Rev., 27:239-261, 2003.

OLIVEIRA, F.C. Metais pesados e formas nitrogenadas em solos tratados com lodo de esgoto. Piracicaba, Escola Superior de Agricultura Luiz de Queiroz, 1995. 90p. (Dissertação de Mestrado)

RAIJ, B.van; ANDRADE, J.C.; CANTARELLA, H. \& QUAGGIO, J.A. Análises químicas para a avaliação da fertilidade de solos tropicais. Campinas, Instituto Agronômico, 2001. 285p 
RAIJ, B. van. New diagnostic techniques, universal soil extractants. Commun. Soil Sci. Plant Anal., 25:799-816, 1994.

REVOREDO, M.D. \& MELO, W.J. Disponibilidade de níquel em solo tratado com lodo de esgoto e cultivado com sorgo. Bragantia, 65:679-685, 2006.

RIBEIRO Jr., J.I. Análises estatísticas: SAEG. Viçosa, MG, Universidade Federal de Viçosa, 2001.

ROACH, W.A. \& BARCLAY, C. Nickel and multiple trace deficiencies in agricultural crops. Nature, 157:696, 1946.

SALISBURY, F.B. \& ROSS, C.W. Plant physiology. Belmont, Wadsworth Publishing Company, 1992. 682p.

SENGAR, R.S.; GUPTA, S.; GAUTAM, M.; SHARMA, A. \& SENGAR, K. Occurrence, uptake and physiological responses of $\mathrm{Ni}$ in plants and its effects on environment. Res. J. Phytochem., 2:44-60, 2008.

SIMS, J.T. Comparision of Mehlich 1 and Mehlich 3 extractants for $\mathrm{P}, \mathrm{K}, \mathrm{Ca}, \mathrm{Mg}, \mathrm{Mn}, \mathrm{Cu}$ and $\mathrm{Zn}$ in Atlantic Coastal Plain soils. Commun. Soil Sci. Plant Anal., 20:1707-1726, 1989.
VITTI, A.C.; TRIVELIN, P.C.O.; GAVA, G.J.C.; PENATTI, C.P. \& OLIVEIRA, M.W. Volatilização de amônia da adubação nitrogenada aplicada sobre solo coberto com palhada de cana-de-açúcar: Efeito na produtividade da cana-soca. In: CONGRESSO NACIONAL DOS TÉCNICOS AÇUCAREIROS E ALCOOLEIROS DO BRASIL, 8., Recife, 2002. Anais... Recife, STAB, 2002. p.239-244.

WHITNEY, D. Micronutrient soil tests for zinc, iron, manganese, and copper. In: DAHNKE, W.C., ed. Recommended chemical soil test procedures for the North Central Region. Columbia, 1988. p.20-22. (North Dakota Agricultural Experiment Station Bulletin, 499)

WITTE, C.D. \& MEDINA-ESCOBAR, N. In-gel detection of urease with nitroblue tetrazolium and quantification of the enzyme from different crop plants using the indophenol reaction. Anal. Biochem., 290:102-107, 2001.

ZAZOSKI, R.J. \& BURAU, R.G. A rapid nitric-perchloric acid digestion method for multi-element tissue analysis. Commun. Soil Sci. Plant Anal., 8:425-436, 1997. 